\title{
Prevalence and Pattern of Renal Bone Disease in End Stage Renal Disease Patients in Ile-Ife, Nigeria
}

\author{
Prévalence et les tendances de la maladie des os rénale chez les patients avec l'insuffisance rénale \\ terminale en Ile-Ife, Nigéria
}

\author{
A. A. Sanusi*, F. A. Arogundade*, M. Oladigbo ${ }^{\dagger}$, L. M. Ogini ${ }^{\dagger}$, A. Akinsola ${ }^{\dagger}$
}

\begin{abstract}
BACKGROUND: Information on renal bone disease (RBD) is sparse in Nigeria. The prevalence of RBD in a dialysis population worldwide ranges between $33 \%$ and $67 \%$ and it increases with progression of renal insufficiency.

OBJECTIVE: To determine the prevalence and magnitude of RBD in patients with end stage renal disease (ESRD).

METHODS: Thirty consecutive ESRD patients were recruited. They had thorough clinical evaluation and investigations which included serum calcium, phosphate, alkaline phosphatase, albumin and skeletal survey. The serum iPTH, osteocalcin, and 1,25 $\left(\mathrm{OH}_{2}\right) \mathrm{D}_{3}$ were assessed in 20 patients.

RESULTS: The patients were aged 18-72 years with a mean of $38.93 \pm 15.7$ years. There was a male:female ratio of $4: 1$. Uraemic symptoms were the major presenting complaints. None of the patients complained of bone pain or fracture. The mean values for serum creatinine, urea, creatinine clearance, calcium, phosphate, albumin, alkaline phosphatase, iPTH, osteocalcin and $1,25(\mathrm{OH})_{2}$ Vit $\mathrm{D}_{3}$ were $1478.96 \pm 771.12$ $\mu \mathrm{mol} / \mathrm{L}, 22.33 \pm 7.42 \mathrm{mmol} / \mathrm{L}, 3.38 \pm 2.22 \mathrm{mls} / \mathrm{min}, 1.8 \pm$ $0.5 \mathrm{mmol} / \mathrm{L}, 1.61 \pm 0.65 \mathrm{mmol} / \mathrm{L}, 30.2 \pm 6.1 \mathrm{~g} / \mathrm{L}, 124.33 \pm$ 63.37 IU/L, $22.66 \pm 24.72,45.14 \pm 43.8,37.7 \pm 22.3$ respectively. There were hypocalcaemia and hyperphosphataemia in $80 \%$ and $60 \%$ of the patients respectively. Alkaline phosphatase was elevated in $44 \%$ of the patients while $11.8 \%$ had hyperparathyroidism. Level of $1,25(\mathrm{OH})_{2}$ Vit $\mathrm{D}_{3}$ was low in $83.3 \%$ of the patients. There was a significant negative correlation between serum calcium and iPTH levels $(\mathrm{r}=\mathbf{- 0 . 9 1 5}, \mathrm{p}=\mathbf{0 . 0 2 9})$. There was also significant negative correlation between alkaline phosphatase and 1,25 $(\mathrm{OH})_{2}$ Vit $D_{3}$ and serum albumin. Radiological evidence of RBD occurred in only $16.7 \%$ of the patients.

CONCLUSION: Renal bone disease is common in our patients with ESRD associated most commonly with low bone turnover while occurrence of hyperparathyroid bone disease appears low. WAJM 2010; 29(2): 75-80.
\end{abstract}

Keywords: End state renal disease, renal bone disease, prevalence.

\section{RÉSUMÉ}

CONTEXTE: Information sur la maladie d'ostéodystrophie rénale $(R B D)$ sont rares au Nigeria. La prévalence de RBD dans une population de dialyse dans le monde entier va entre $33 \%$ et $67 \%$ et elle augmente avec la progression de l'insuffisance rénale.

OBJECTIF: Déterminer la prévalence et l'ampleur de RBD chez les patients souffrant d'insuffisance rénale chronique au stade final (IRT). MÉTHODES: Trente patients consécutifs ont été recrutés IRT. Ils avaient l'évaluation clinique approfondie et des enquêtes qui comprenait calcémie, la phosphatémie, phosphatase alcaline, l'albumine et à l'étude squelettique. Le iPTH sérique, l'ostéocalcine, et de 1,25( $\left(\mathrm{OH}_{2}\right)_{3}$ D ont été évaluées chez 20 patients.

RÉSULTATS: Les patients étaient âgés de 18-72 ans avec une moyenne de 38,93 $\pm 15,7$ ans. Il y avait un ratio hommes / femmes est de 4:1. symptômes urémiques ont été l'introduction des requêtes principales. Aucun des patients se plaignaient de douleurs osseuses ou des fractures. Les valeurs moyennes pour la créatinine sérique, l'urée, la clairance de la créatinine, le calcium, le phosphate, l'albumine, de phosphatase alcaline, PTHi, l'ostéocalcine et de 1,25 (OH $)_{2}$ vitamine $D_{3}$ ont été $1478,96 \pm 771,12 \mathrm{mmol} / \mathrm{L}, 22,33 \pm 7,42 \mathrm{mmol} / \mathrm{L}, 3,38 \pm$ $2,22 \mathrm{ml} / \mathrm{min}, 1,8 \pm 0,5 \mathrm{mmol} / \mathrm{L}, 1,61 \pm 0,65 \mathrm{mmol} / \mathrm{L}, 30,2 \pm 6,1 \mathrm{~g}$ $/ L, 124,33 \pm 63,37 U I / L, 22,66 \pm 24,72,45,14 \pm 43,8,37,7 \pm 22,3$, respectivement. Il ya eu une hypocalcémie et une hyperphosphatémie chez $80 \%$ et $60 \%$ des patients respectivement. La phosphatase alcaline était élevée chez $44 \%$ des patients alors que $11,8 \%$ avaient une hyperparathyroïdie. niveau de 1,25 (OH) vitamine $D_{3}$ a été faible dans $83,3 \%$ des patients. Il y avait une corrélation négative significative entre la calcémie et iPTH niveaux ( $r=-0,915, p=0,029)$. Il a également été importante corrélation négative entre la phosphatase alcaline et de 1,25 (OH $)_{2}$ vitamine $D_{3}$ et de l'albumine sérique. des signes radiologiques de RBD eu lieu dans seulement 16,7\% des patients.

CONCLUSION: ostéodystrophie rénale est fréquente chez nos patients en insuffisance rénale terminale associée le plus souvent avec le remodelage osseux bas, tandis que apparition de la maladie osseuse hyperparathyrö̈die semble faible. WAJM 2010; 29(2): 75-80.

Mots-clés: état de la maladie rénale End, ostéodystrophie rénale, la prévalence.

*Department of Medicine Obafemi Awolowo University Teaching Hospitals Complex, Ile-Ife.

'Department of Orthopaedic Surgery, Obafemi Awolowo University Teaching Hospitals Complex, Ile-Ife.

Correspondence: E-mail: fatiu3@yahoo.com

Abbreviations: CKD, Chronic kidney disease; CRF, Chronic renal failure; ESRD, End stage renal disease; GFR, Glomerular filtration rate; ICMA, Immunochemiluminometric; KDIGO, Kidney disease improving global outcomes; RBD, Renal bone disease; ROD, Renal osteodystrophy; MBD, Mineral bone disorder PCV, packed cell volume; PTH, parathormone. 


\section{INTRODUCTION}

Renal bone disease (RBD) otherwise referred to as renal osteodystrophy (ROD) encompasses the various metabolic bone disorders seen in patients with chronic renal failure (CRF). ${ }^{1}$ It has been established to be a consequence of abnormal bone and mineral metabolism and contributes significantly to morbidity in CRF patients. ${ }^{2}$ ROD occurs early in the course of CRF as up to $50 \%$ of patients in whom glomerular filtration rate (GFR) has been reduced to half of normal value have abnormal bone histology. ${ }^{3}$ In advanced CRF almost all patients have abnormal bone histology. ${ }^{4}$ A new classification was introduced by the Kidney Disease Improving Global Outcomes (KDIGO) in 2005..$^{5}$ The panel concluded that the features of bone and mineral disease were diverse and included extraskeletal manifestations which necessitated a new classification. ${ }^{5}$ Chronic Kidney Disease (CKD) - Mineral Bone Disorder (MBD) is defined as a systemic disorder of mineral and bone metabolism due to CKD manifested by one or a combination of any of the following, (i) abnormalities of calcium, phosphorus, PTH or vitamin D metabolism, (ii) abnormalities of bone turnover, mineralisation, volume, linear growth or strength and/or (iii) vascular or other soft tissue calcification. ${ }^{5}$ The panel defined ROD as an alteration in bone morphology in patients with CKD. ${ }^{5}$

Chronic renal failure is very prevalent in developing countries and has been reported to constitute 6-8\% of medical admissions in western Nigeria. ${ }^{6-8}$ Despite this magnitude of CRF, renal bone disease is said to be rare and in fact literature is sparse on its existence amongst our CRF population. In a recent publication, however, Onyemekeihia found hypocalcaemia and hyperphosphataemia in $71 \%$ and $79 \%$ of their CRF patients respectively and in addition $90 \%$ of those that had bone biopsies had histological evidence of renal bone disease. ${ }^{9}$ Boner et $a l^{10}$ in Israel reported prevalence of ROD to be $66.7 \%$ while the Egyptian renal dialysis registry ${ }^{11}$ reported a prevalence of $33.3 \%$ among dialysis patients. In the Czech Republic, the prevalence of renal osteodystrophy was found to be $57 \%$ among uraemic patients. $^{12}$
Renal osteodystrophy manifests with bone pain and tenderness with occasional fractures; it could be very severe and incapacitating. Hypocalcaemia (with hyperphosphataemia) is the primary event triggering hyperparathyroidism and bone remodelling, a process aimed at achieving a balance between the processes of osteoblastic bone formation and osteoclastic bone resorption. $^{13}$

There are two major types; High turnover bone disease which includes osteitis fibrosa cystica, mild osteitis fibrosa (mild hyperparathyroid bone disease) and mixed uraemic bone disease and Low turnover bone disease, which includes osteomalacia and adynamic/ aplastic bone disease.

The relative prevalence of each of these types varies in different communities and with different dialysis modalities. In Thailand, Jaros et $a l^{14}$ reported the following types of ROS in decreasing order of prevalence: adynamic bone disease, hyperparathyroid bone disease, mixed uraemic bone disease, mild lesion, osteomalacia and osteosclerosis which were seen in $41.1 \%, 28.6 \%, 19.6 \%, 5.4 \%, 3.6 \%$ and $1.8 \%$ respectively. A report on 1,209 bone biopsies from five different countries (Brazil, Uruguay, Argentina, Portugal, and Spain) showed that low turnover osteomalacia and mixed uraemic osteodystrophy were more common in Brazil, Uruguay, and Argentina while hyperparathyroid bone disease predominated the picture in Portugal and Spain. ${ }^{15}$ In the series reported by Onyemekehia ${ }^{9}$, osteitis fibrosa cystica was the commonest histological lesion found on bone biopsies.

Bone biopsy though very invasive, remains the most informative diagnostic tool and provides information on the type and severity of ROD. ${ }^{16}$ Radiological and biochemical investigations could be used where biopsy could not be done. Abnormalities have been noted on radiographs in approximately $40 \%$ to $50 \%$ of patients who show increased resorptive surfaces on bone biopsy specimens. ${ }^{4,16,17}$

Intrigued by the relatively sparse literature on renal bone disease in our environment we set out to establish the occurrence, pattern and magnitude of renal osteodystrophy in our CRF patients to be able to add to available body of knowledge.

This study therefore sought to assess the occurrence and magnitude of ROD in our CRF patients, determine the types and ascertain the relationship between the clinical features of ROD and the biochemical and radiological findings.

\section{SUBJECTS, MATERIALS, AND METHODS}

This study was carried out at the renal unit, Obafemi Awolowo University Teaching Hospitals Complex, Ile-Ife, Nigeria, between January 1998 and June 2005.

Forty patients with established CRF were recruited into the study after a written informed consent. The diagnosis of chronic renal failure as well as categorisation of the aetiology was done according to established clinical, laboratory and radiologic criteria. ${ }^{18,19}$ Such criteria include long standing history of hypertension or body swelling, frothiness of urine, features of uraemia ie nausea, vomiting, hiccups, pruritus, recurrent urinary tract obstruction and renal ultrasonographic appearance of shrunken, polycystic or hydronephrotic kidneys.

The exclusion criteria included; diabetic nephropathy, treatment with steroids or anticonvulsants or antacids, sickle cell disease or trait, post menopausal females, presence of thyroid or parathyroid disease and multiple myeloma and patients with end-stage renal disease on renal replacement therapy.

Recruited patients were taken through a thorough and comprehensive evaluation using a standard questionnaire to determine the causes, severity and complications of chronic renal disease, establish features of renal bone disease and identify agents that may modify features of renal bone disease.

A comprehensive evaluation of the history, physical examination and laboratory investigations was carried out. The following demographic parameters were sought; age, sex and occupation. 
In addition, details of all the relevant symptoms at presentation and their duration and use of renal replacement therapy (duration and type) etc were taken. Also history of alcohol consumption, steroid, aluminium hydroxide (duration and dosages) or anticonvulsant use as well as environmental exposures (aluminium) was sought. Detailed physical and systemic examination was performed to establish the presence or otherwise of anaemia, uraemia, body swelling, bone and muscle tenderness or even fractures. A comprehensive evaluation of renal and hepatic function was carried out using the following indices, serum electrolytes, urea, creatinine, calcium, phosphate, serum proteins (albumin and globulin), cholesterol, alkaline phosphatase, alanine and aspartate transaminases. Creatinine clearance was estimated for all patients using Cockroft and Gault formula because of the high correlation reported by Sanusi et $a l^{20}$ as follows:

Creatinine Clearance
$\mathrm{mls} / \mathrm{min}$$\overline{\overline{7} 2(\text { Serum Creatinine })}$

[Wt is in $\mathrm{kg}$, age in years and serum creatinine in $\mathrm{mg} / \mathrm{dl}$; in females multiply by 0.85$]$.

Haematological investigations; included packed cell volume (PCV), total/ differential leucocyte count, blood film for red cell morphology, platelet count and when necessary reticulocyte count and index. Twenty samples were sent to Charles salt centre UK, for assays of the levels of parathormone (PTH), 1,25 dihydroxy cholecalciferol and osteocalcin as they were not routinely assayed in our centre. The assay method used for PTH was immunochemiluminometric (ICMA) ${ }^{21,22}$ Osteocalcin was assayed by an enzyme immunoassay, which recognise the intact molecule of osteocalcin.

X-ray of the chest (PA-view), hands, hip and skull was performed on all the patients to be able to determine cardiothoracic ratio, arterial wall calcification and features of renal osteodystrophy such as subperiosteal erosion, new bone formation, pepper pot skull, looser zones, cysts or osteosclerosis etc. Renal ultrasonography was performed on all patients to document features of chronic renal disease such as reduced bipolar and transverse diameters; increased echogenicity and loss of corticomedullary differentiation.

\section{Statistical Analysis}

The data were analyzed using statistical package for social sciences SPSS package version 10. Descriptive statistics such as range, mean and standard deviation were used to describe continuous variables while numbers and percentages were used to present discreet variables. Spearman's coefficient of correlation as well as multiple regression analysis were used to establish associations between clinical and biochemical findings. Chi square or Fisher's exact tests were used to test association between radiological features and laboratory parameters. A 95\% confidence interval was used for the determination of significance of probabilities ie the difference was significant when $\mathrm{p}$ was $<0.05$.

\section{RESULTS}

Forty patients aged between 18 and 70 years (mean $\pm S D ; 38.83 \pm 14.69$ years) completed the study, with 32 (80\%) being males and females $8(20 \%)$. Fifty-two percent of them were artisans while $27.5 \%$ were either students or unemployed and $20 \%$ were civil servants.

The duration of CRF ranged from 3 months to 96 months (mean \pm SD; $38.83 \pm$ 14.69 months). Aetiology of chronic renal failure was hypertension in $16(40 \%)$, chronic glomerulonephritis in $15(37.5 \%)$, obstructive uropathy in $4(10 \%)$ and polycystic kidney disease in $1(2.5 \%)$ patient. The aetiology was not known in $4(10 \%)$ patients.

Uraemic symptoms were the major presenting complaints in $30(75 \%)$ while $16(40 \%)$ of the patients presented with features of cardiac failure. Even though all the patients complained of general lassitude only $2(5 \%)$ complained of bone pains. There was no case of pathological fractures.

Majority of the patients were offered haemodialysis $35(88 \%)$ while five $(12 \%)$ benefited from intermittent peritoneal dialysis. Duration of renal replacement therapy ranged between 1 and 18 weeks. All the patients were in end stage renal disease with mean creatinine clearance of $5.44 \pm 3.20 \mathrm{mls} / \mathrm{min}$. The mean values for serum creatinine, urea, sodium, bicarbonate and potassium are shown in Table 1. Twenty-nine (72\%) of the patients had hypoalbuminaemia (serum albumin less than $35 \mathrm{~g} / \mathrm{L}$ ), which necessitated correction factor for serum calcium. The mean serum albumin, calcium, phosphate, intact $\mathrm{PTH}$, osteocalcin and active Vit $\mathrm{D}_{3}$ are as shown on Table 1.

\section{Table 1: Serum Analytes in 40 Study Patients}

\begin{tabular}{lc}
\hline $\begin{array}{l}\text { Serum } \\
\text { Variable }\end{array}$ & Mean $($ SD $)$ \\
\hline Creatinine $(\mu \mathrm{mol} / \mathrm{L})$ & $1466.45(733.81)$ \\
Urea $(\mathrm{mmol} / \mathrm{L})$ & $22.17(6.36)$ \\
Sodium $(\mathrm{mmol} / \mathrm{L})$ & $131.5(7.8)$ \\
Potassium $(\mathrm{mmol} / \mathrm{L})$ & $4.62(0.97)$ \\
Bicarbonate $(\mathrm{mmol} / \mathrm{L})$ & $18.16(1.74)$ \\
Albumin $(\mathrm{g} / \mathrm{L})$ & $30.84(6.34)$ \\
Corrected serum calcium & \\
$(\mathrm{mmol} / \mathrm{L})$ & $2.00(0.50)$ \\
Phosphate $(\mathrm{mmol} / \mathrm{L})$ & $1.82(0.51)$ \\
Calcium-Phosphate product & \\
$\left(\right.$ mmol $\left.^{2} / \mathrm{L}^{2}\right)$ & $3.49(0.97)$
\end{tabular}

$\left(\mathrm{mmol}^{2} / \mathrm{L}^{2}\right)$

$3.49(0.97)$

Alkaline phosphatase

(IU/L)

$130.33(60.50)$

Intact PTH (pmol/L)*

26.71(24.82)

Osteocalcin $(\mathrm{pmol} / \mathrm{L})^{\dagger}$

45.14(43.81)

Active Vitamin $\mathrm{D}_{3}(\mathrm{pmol} / \mathrm{L}) \$ 37.71(22.30)$

*, $\mathrm{N}=14 ;{ }^{\dagger}, \mathrm{N}=14 ;{ }^{\ddagger}, \mathrm{N}=12$. Mean glomerular filtration rate was $5.44(3.20) \mathrm{mls} / \mathrm{min}$.

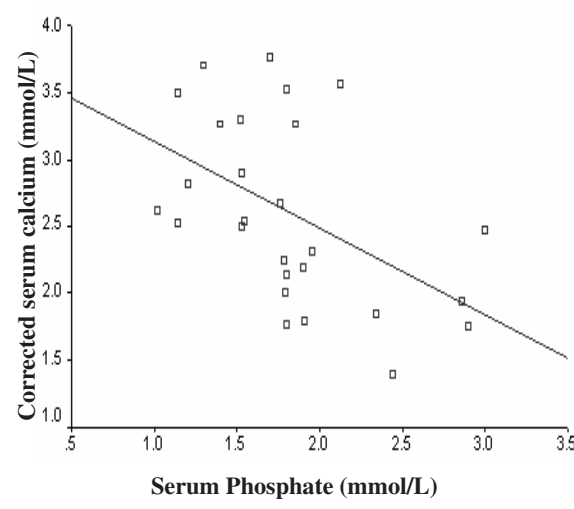

Figure 1: Relationship between corrected serum calcium and phosphate $(r=-0.567$, $\mathbf{p}=\mathbf{0 . 0 0 2}$ ) 
Table 2: Relationship between Radiological Features and other Variables

\begin{tabular}{|c|c|c|c|c|}
\hline \multirow[t]{2}{*}{ Variable } & & \multicolumn{2}{|c|}{ Radiological Features } & \multirow{2}{*}{$\begin{array}{l}\text { P-value } \\
\text { (Fishers } \\
\text { Exact Test) }\end{array}$} \\
\hline & & Osteodystrophy & Normal & \\
\hline \multirow[t]{2}{*}{ Gender } & Male & 8 & 24 & \multirow[t]{2}{*}{0.6553} \\
\hline & Female & 1 & 7 & \\
\hline \multirow{2}{*}{$\left.\begin{array}{l}\text { Serum Phosphate } \\
(\mathrm{mmol} / \mathrm{L})\end{array}\right\}$} & $<1.7$ & 2 & 11 & \multirow[t]{2}{*}{0.6925} \\
\hline & $>1.7$ & 7 & 21 & \\
\hline Corrected Serum & $<2.25$ & 6 & 18 & \multirow[t]{2}{*}{1.000} \\
\hline Calcium $(\mathrm{mmol} / \mathrm{L})$ & $>2.25$ & 3 & 12 & \\
\hline Calcium-Phosphate & $<4.5$ & 7 & 28 & \multirow[t]{2}{*}{0.3114} \\
\hline Product $\left(\mathrm{mmol}^{2} / \mathrm{L}^{2}\right)$ & $>4.5$ & 2 & 3 & \\
\hline Serum Alkaline & $<110$ & 4 & 17 & 1.000 \\
\hline Phosphatase (IU/L) & $>110$ & 5 & 14 & \\
\hline \multirow[t]{2}{*}{ Intact PTH $(\mathrm{pmol} / \mathrm{L})\}$} & $<31$ & 2 & 9 & \multirow[t]{2}{*}{1.000} \\
\hline & $>31$ & 0 & 3 & \\
\hline \multirow{2}{*}{$\begin{array}{l}\text { Active Vitamin } \mathrm{D}_{3} \\
(\mathrm{pmol} / \mathrm{L})\end{array}$} & $<60$ & 1 & 9 & \multirow[t]{2}{*}{0.3182} \\
\hline & $>60$ & 1 & 1 & \\
\hline \multirow[t]{2}{*}{ Osteocalcin $(\mathrm{pmol} / \mathrm{L})\}$} & $<50$ & 1 & 11 & \multirow[t]{2}{*}{0.5149} \\
\hline & $>50$ & 1 & 4 & \\
\hline
\end{tabular}

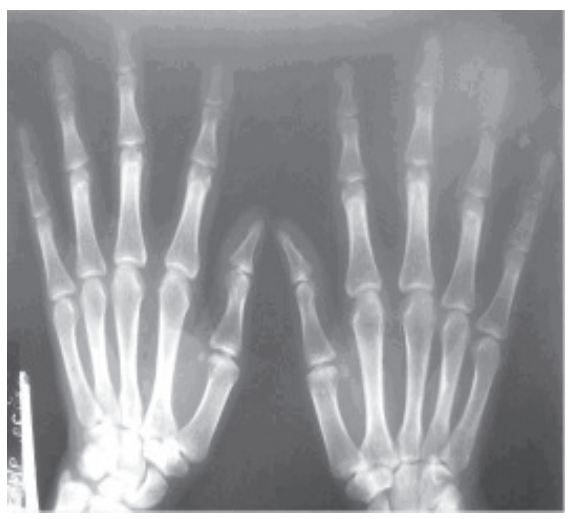

Figure 2: X-ray of the hands showing peri-articular osteopenia.

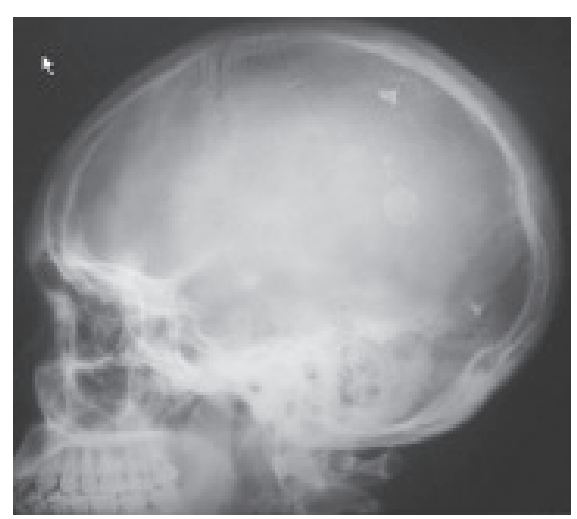

Figure 3: X-ray of the skull showing pepper pot appearance.
Serum calcium was greater than 2.55 $\mathrm{mmol} / \mathrm{L}$ in $7.4 \%$ of the patients, ranged between 2.25 and $2.55 \mathrm{mmol} / \mathrm{L}$ in $33.3 \%$ and there was hypocalcaemia in $59.3 \%$. In contrast there was hyperphosphataemia in $75 \%$ of the patients while the remaining $25 \%$ had serum phosphate less than $1.5 \mathrm{mmol} / \mathrm{L}$ There was elevated calcium phosphate product $\left(>4.55 \mathrm{mmol}^{2} / \mathrm{L}^{2}\right)$ in $12.5 \%$ of the patients. Serum intact PTH was assessed in 14 patients, values were normal in $24 \%$, ranged between 6 and $15 \mathrm{pmol} / \mathrm{L}$ in $18 \%$, and between 16 and $30 \mathrm{pmol} / \mathrm{L}$ in another $40 \%$ of the patients. It was moderately elevated (31-90 pmol/L) in $18 \%$ of the patients. Osteocalcin levels were assessed in 17 patients, it was less than $50 \mathrm{pmol} / \mathrm{L}$ in $70 \%$, ranged between 50 and $100 \mathrm{pmol} / \mathrm{L}$ in $12 \%$ and was above $100 \mathrm{pmol} / \mathrm{L}$ in $18 \%$ of the patients. Also serum active Vit D3 assessment results revealed low level $(<60 \mathrm{pmol} / \mathrm{L})$ in $83 \%$ of the patients while the remaining patients had higher values.

There were hypocalcaemia and hyperphosphataemia in $59.3 \%$ and $75 \%$ of the patients respectively. Alkaline phosphatase was elevated in $42.9 \%$ of the patients while only $18 \%$ had hyperparathyroidism. 1,25 $(\mathrm{OH})_{2}$ Vit $\mathrm{D}_{3}$ was low in $83.3 \%$ of the patients. There was a significant negative correlation between serum bicarbonate and serum creatinine, urea and creatinine clearance with corresponding coefficients of $0.502,-0.486$ and -0.526 and 'p' values of $0.002,0.003$ and 0.001 respectively. However on correcting for the glomerular filtration rate $(\hat{a}=0.401, \mathrm{p}=0.019)$ on multiple regression analysis, the observed correlation disappeared. Also active Vit D level significantly positively correlated with corrected serum calcium $(\mathrm{r}=0.74, \mathrm{p}=0.036)$ and negatively with serum alkaline phosphatase $(\mathrm{r}=-0.712$, $\mathrm{p}=0.048$ ). There was a weak correlation between calculated creatinine clearance and active Vit D level with tendency towards statistical significance $(r=590$, $\mathrm{p}=0.056$ ). Similarly, serum albumin significantly negatively correlated with calcium-phosphate product $(\mathrm{r}=-0.697$, $\mathrm{p}<0.0001)$ and alkaline phosphatase $(\mathrm{r}=$ $-0.556, \mathrm{p}=0.009$ ), though on multiple regression analysis only alkaline phosphatase correlated with 'â' value of -0.556 and ' $p$ ' value of 0.011 .

Of the $9(23 \%)$ of patients who had radiographic features all had periarticular osteopenia while six had multiple dot-like luscencies 'pepper-pot' skull and five had osteopenia of pelvic bones. There was no association between gender, serum calcium, phosphate, vit D, PTH and osteocalcin levels and radiological features of RBD (Table 2).

\section{DISCUSSION}

Renal osteodystrophy hitherto thought to be rare in Nigeria, is now increasingly being recognised. This study found hypocalcaemia and hyperphosphataemia in $59.3 \%$ and $75 \%$ of the end stage renal disease patients respectively underscoring the magnitude of renal bone disease in this population. This is in agreement with the findings of reports from University of Benin Teaching Hospital. ${ }^{9}$ Hyperphosphataemia is now recognised as the primary initiator of the various cascades of the promoters of renal bone disease. It triggers parathyroid hyperplasia, secondary hyperpapathyroidism, metastatic calcification and is now recognised to significantly influence mortality in CRF patients. ${ }^{13,23-25}$ This 
study also found a significant negative correlation between serum phosphate and corrected calcium, which further confirms the reciprocal relationship between both as has been recognised by previous works. ${ }^{26}$

Even though, only a small percentage of the patients had assays of intact parathormone (PTH), active Vitamin D and osteocalcin done, secondary hyperparathyroidism was detected in only $18 \%$, this is in sharp contrast to the findings in Benin where osteitis fibrosa was found in 9 of the 10 bone biopsies performed though serum PTH was not assayed. The pattern of renal bone disease is changing worldwide with the prevalence of hyperparathyroid bone disease and consequent osteitis fibrosa declining while that of low turnover or adynamic bone disease is increasing. This is thought to be due to early introduction of various vitamin D analogues in the management of CRF, increasing age, rising incidence of diabetes mellitus as well as use of high calcium dialysate. ${ }^{27-29}$ The low incidence of osteomalacia has been linked with the reduced use of aluminium based antacids or dialysis fluids in CRF patients. In agreement with the low percentage of hyperparathyroidism in our patients, the levels of osteocalcin, a marker of bone turnover was found to be normal or low in majority of our patients. ${ }^{29}$

Osteocalcin, a vitamin $\mathrm{K}$ dependent protein produced by the osteoblast is the most abundant noncollagenous protein of bone and its levels reflect bone formation. It is increased in CRF because of reduced renal clearance of the protein but it has been found to be useful in distinguishing patients with highturnover from those with low-turnover bone lesions such as osteomalacia and adynamic bone disease. Malluche et $a l^{30}$ found relationships between the plasma level of osteocalcin, histologic parameters of bone turnover, and the degree of peritrabecular fibrosis in patients undergoing maintenance dialysis. Baskin et $a l^{31}$ also found a correlation between osteocalcin and intact PTH as well as bone specific alkaline phosphatase. In contrast this study did not find any significant correlationship between osteocalcin and
PTH or serum alkaline phosphatase despite the fact that $30 \%$ of our patients had levels above 50pmol/L this may be because of the smallness of the sample size.

With marked diminution in functioning renal mass as CRF progresses, the levels of active Vitamin $\mathrm{D}_{3}$ usually decline, it is therefore not surprising that majority of our patients $(83 \%)$ that had vitamin D assessment done had low levels. The weak correlationship between creatinine clearance and Vit D level found in this study may be a reflection of the sample size. The positive correlation between serum calcium and active Vitamin D is expected as active Vitamin D increases calcium absorption from the gut, this is in agreement with previous works. ${ }^{32}$ Low calcitriol levels have also been found in most studies of patients with mild to moderate renal failure (GFR 40 to $80 \mathrm{ml}$ / $\min ){ }^{33}$

Even though radiological detection of renal bone disease was generally low, the $23 \%$ detection rate found in our study was higher than $3.35 \%$ and $2 \%$ reported by Odenigbo et $a l^{34}$ and Onyemekeihia ${ }^{9}$ respectively. This is probably because of the severity of CRF in our study population and may also be due to parts of the body selected. This study found periarticular osteopenia affecting the phalanges, pepper pot skull and pelvic bone osteopenia in $100 \%, 67 \%$ and $55 \%$ of the patients who had radiologic features respectively. Lye et $\mathrm{al}^{35}$ correlated skeletal survey with biochemical findings and found renal bone disease in $24.4 \%$ of patients in agreement with our finding. However the lack of correlation or association between PTH and osteocalcin levels and radiological features of osteodystrophy may have been due to the small sample size.

Majority of our patients were not symptomatic of bone disease as only two of the forty complained of bone pain and no case of pathological fracture was recorded despite the advanced nature of the CRF. It may well be that the other effects of uraemia eg anaemia and possibly cardiac failure masked that of bone disease in these patients since presentation was usually late. On the contrary, this may be due to the protective nature of our diet and adequate exposure to sunlight offered by our tropical weather. The rapid progression usually reported in our patients may equally account for this observation. It must be noted however that the two earlier reports also documented paucity of clinical features of bone disease in our patients. $^{9,34}$

In conclusion, this study, like that of colleagues from other parts of the Nigeria clearly revealed the preponderance of features of renal osteodystrophy in our chronic renal failure patients, there is therefore the need to pay special attention to indices of this disabling complication. Hyperphosphataemia and hypocalcaemia, which are recognised primary initiators, should be closely monitored and controlled. Early introduction of Vit D analogues and calcimimetic drugs is advocated to further reduce the contributions of renal osteodystrophy to the horrendous morbidity and mortality of our chronic renal failure and consequently end stage renal failure patients. There is the need to have assays of intact parathormone, active Vit D and osteocalcin in our normal population, which is currently unavailable. There is also the need to further assess the magnitude of the renal bone disease possibly in a multi-centre study and in particular evaluate its contributions to mortality in our setting.

\section{ACKNOWLEDGEMENTS}

We acknowledge the support of Dr Sharp C of Charles Salt Centre UK, who assisted with the assays of PTH, Osteocalcin and Vit $\mathrm{D}_{3}$.

\section{REFERENCES}

1. Reiss E, Canterbury JM, Egdahl RH. Measurement of serum parathyroid hormone in renal insufficiency. Trans Assoc Am Phys. 1968; 81: 104-115.

2. Arnaud CD. Hyperparathyroidism and renal failure. Kidney Int 1973; 4: 8995.

3. Smith A, Faugere M, Abreo K. Aluminium associated bone disease in renal failure. A study on prevalence, histopathology, aetiology and diagnosis in 197 patients. Am J Nephrol. 1986; 6: 275-283.

4. Hutchison AJ, Whitehouse RW, Boulton HF, Adams JE, Mawer EB, 
Freemont TJ, et al. Correlation of bone histology with parathyroid hormone, vitamin D3 and radiology in end stage renal disease. Kidney Int. 1993; 44: 1071-7.

5. Moe S, Drueke T, Cunningham I, Cannata-Andía JB, Elder GJ, Fukagawa $\mathrm{M}$, et al. Definition, evaluation and classification of renal osteodystrophy: A position statement from Kidney Disease: Improving Gllobal Outcomes (KDIGO). Kidney Int 2006; 69: 194553.

6. Akinsola W, Odesanmi WO, Ogunniyi JO, Ladipo GO. Diseases causing chronic renal failure in Nigerians: a prospective study of 100 cases. Afr J Med Med Sci. 1989 18: 131-7.

7. Kadiri S, Arije A. Temporal variations and meterological factors in hospital admissions of chronic renal failure in south West Nigeria. West Afr J Med 1999; 18: $49-51$.

8. Akinsola A, Akinkugbe OO. Chronic renal failure in the tropics, clinical features and strategies in management. Postgraduate Doctor. 1989; 12: 11181130.

9. Onyemekeihia R, Renal osteodystrophy in Benin. A dissertation submitted to the National Postgraduate Medical College of Nigeria, Faculty of Internal Medicine November 2004.

10. Boner G, Olah AJ, Weiss A, Seelenfreund MZ, Rosenfeld JB. Renal osteodystrophy in end-stage renal failure patients in Israel. Isr J Med Sci 1983;19: 608-13.

11. Second annual report of the Egyptian Society of Nephrology, 1997: http:// http://163.121.19.91/esnnew/ data1997.htm

12. Jaros A, Zadrazil J, Konecny K, Kosatíková Z, Zahálková J, Vrublovský $\mathrm{P}$, et al. Single photon bone densitometry in hemodialysis patients. Acta Univ Palacki Olomuc Fac Med 1999; 142: 135-8.

13. Llach F. Hyperphosphataemia in end stage renal disease patients: pathophysiological consequences. Kidney Int. 1999; 56: S31-S37.

14. Changsirikulchai S, Domrongkitchaiporn S, Sirikulchayanonta V, Ongphiphadhanakul B, Kunkitti N,
Stitchantrakul W, et al. Renal osteodystrophy in Ramathibodi Hospital: histomorphometry and clinical correlation. J Med Assoc Thai 2000; 83: 1223-32.

15. Jorgetti V, Lopez BD, Caorsi H, Ferreira A, Palma A, Menendez $\mathrm{P}$, et al. Different patterns of renal osteodystrophy in Iberoamerica. Am J Med Sci 2000; 320: 76-80.

16. Malluche HH, Langub MC, MounierFaugere M. The role of bone biopsy in clinical practice and research. Kidney Int. 1999; 56: S20-S25.

17. Adams JE. Renal bone disease: radiological investigation. Kidney Int. 1999: 56 (suppl 73): S38-S41.

18. Adelekun A, Akinsola A. Hypertension induced chronic renal failure: Clinical features, management and prognosis. West Afr J Med 1998; 17: 104-8.

19. Ojogwu LI. Pathologic basis of end stage renal disease in Nigeria: Experience from Benin. West Afr J Med 1990; 9: 193-6.

20. Sanusi AA, Akinsola A, Ajayi AA. Creatinine clearance estimation from serum creatinine values: evaluation and comparison of five prediction formulae in Nigerian patients. Afr J Med Med Sci. 2000; 29: 7-11.

21. Endres DB, Villanueva R, Sharp CF Jr, Singer FR. Immunochemiluminometric and immunoradiometric determinations of intact and total immunoreactive parathyrin: Performance in the differential diagnosis of hypercalcemia and hypoparathyroidism. Clin Chem 1991; 37: 162-8.

22. Michelangeli, VP, Heyma, P, Colman, PG, Ebeling PR. Evaluation of a new, rapid and automated Immunochemiluminometric assay for the measurement of serum intact parathyroid hormone. Ann Clin Blochem 1997; 34: 97-103.

23. Statopolsky E, Bricker NS. The role of phosphorus restriction in the prevention of secondary hyperparathyroidism in chronic kidney disease. Kidney Int. 1973; 4: 141-5.

24. Hsu CH. Are we mismanaging calcium and phosphate metabolism in renal failure? Am J Kidney Dis 1997; 29: 6419.
25. Combe C, Aparicio M Phosphorus and protein restriction and parathyroid function in chronic renal failure. Kidney Int. 1994; 46: 1381-6.

26. Jara A, Chacón C, Felsenfeld AJ. How dietary phosphate, renal failure and calcitriol administration affect the serum calcium-phosphate relationship in the rat. Nephrol Dial Transplant. 2002; 17: 765-71.

27. Malluche, HH, Monier-Faugere, MC. Risk of adynamic bone disease in dialyzed patients. Kidney Int Suppl 1992; 38: S62-S67.

28. Moe SM, Sprague SM. Mineral Bone Disorders in Chronic Kidney Disease. In Brenner B Eds. The Kidney W.B Saunders 2008; Chapter 52: 1784-1813.

29. Krpan D, Lajtman Z, Erceg I, Ivcosic A. Renal Osteodystrophy Based on Bone Histomorphometry: 20 Years of Experience. Dialysis \& Transplantation 2004; 33: 476-482.

30. Malluche HH, Faugere MC, Fanti P, Price PA: Plasma levels of bone Glaprotein reflect bone formation in patients on chronic maintenance dialysis. Kidney Int 1984; 26: 869-874.

31. Baskin E, Besbas N, Saatci U, Hasçelik G, Topaloðlu R, Ozen S, et al. Biochemical markers of bone turnover in the diagnosis of renal osteodystrophy in dialysed children. Turk $J$ Paediatrics 2004; 46: 28-31.

32. Weinstein, RS, Underwood, JL, Hutson, MS, DeLuca, HF. Bone histoplasmorphometry in vitamin Ddeficient rats infused with calcium and phosphorus. Am J Physiol 1984; 246: E499-E505.

33. Meema HE, Rabinovich S, Meema S, Lloyd GJ, Oreopoulos DG. Improved radiological diagnosis of azotemic osteodystrophy. Radiology 1972; 102: $1-10$.

34. Odenigbo UC, Ijoma CK, Ulasi I, Udeh AC, Ibeh CC. The prevalence of radiological markers of renal osteodystrophy in patients with chronic renal failure in Enugu. Niger J Clin Pract. 2006; 9: 147-52.

35. Lye WC; Lee EJ. Renal bone disease in patients on haemodialysis: biochemical and radiological assessment. Ann Acad Med Singapore 1992; 2: 760-4. 